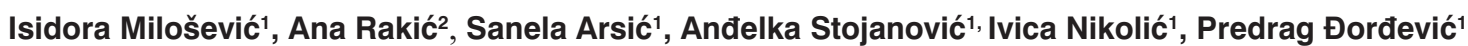

${ }^{1}$ University of Belgrade, Technical faculty in Bor, Serbia

${ }^{2}$ University of Belgrade, Faculty of Organizational Sciences, Serbia

\title{
Model for Considering the Propensity of Students to Accept M-learning
}

\author{
DOI: 10.7595/management.fon.2020.0021
}

\begin{abstract}
:
Research question: The aim of the study is to examine the inclination of engineering students in Serbia to adopt Mlearning. Motivation: Mobile technologies provide new solutions in the current concept of learning. Students today have a new approach to learning since they live in the era of digital technology. The use of mobile technology in higher education came along with the technological enlightenment of professors and students, eradicating geographical boundaries and enabling cooperative learning. Idea: Mobile learning (M-learning) is unthinkable without the use of mobile devices and it plays an increasingly important role in the development of teaching methods in higher education. The research refers to the analysis and assessment of M-learning in higher education with the aim to identify problems and weaknesses related to the application of M-learning in order to set alternatives and criteria for the proposed model. Data: The survey was conducted through a questionnaire, and 341 correctly filled out questionnaires were collected. The obtained data were processed by the Visual Promethee software package. Tools: The research methodology was based on the Multi-criteria decision analysis (MCDA) method which was used in the form of PROMETHEE II/GAIA technique. In order to rank the student programmes from different study areas, groups of questions were used as criteria, and study programmes were used as alternatives. Findings: The acquired results indicated that M-learning was mostly used by the students of Engineering Management, since they frequently used mobile technology in certain required courses, as well as for obligatory business practice. It was also concluded that the study programme Metallurgical Engineering had the lowest performance concerning the implementation of M-learning among all other observed study programmes. Contribution: The conclusions of this study can add to the awareness-raising of the higher education institutions' interested parties and alert them to improve the quality of M-education by pointing out that there are differences in the adoption of M-learning depending on the type of engineering sciences.
\end{abstract}

Keywords: M-learning, Ranking, Students Programs, Engineering Sciences, MCDA

JEL Classification: I23

\section{Introduction}

Modern technologies and globalization bring rapid changes to all aspects of human life (Alioon \& Delialioglu, 2015). According to the research of Bower et al. (2010) in which the possibilities of new technologies through the application of mobile devices were described as "creating a new kind of reality, in which physical and digital environments, media and interactions are woven together throughout our daily lives", the concept of socialization increasingly gained new dimensions in transformation of lifestyle and habits of citizens.

A daily creation of new information and a general tempo of development of society continuously require the improvement and endorsement of new knowledge and skills. Therefore, there is a constant need for faster, timely information that is readily available at all times (Wen-Hsiung et al., 2012; Milosevic et al., 2015). Advances in technology, such as wide availability of Wi-Fi, Bluetooth, wireless LAN, and global wireless 
technologies such as GSM, GPRS, 3G, LTE, and GPS provide opportunities for a new way of learning to users around the world.

In addition, the expansion of the use of information technology, computers, tablets, and smartphones has raised educational opportunities and opened the way for a new approach to learning known as M-learning. The high availability of information technologies and the ease and comfort of their use have significantly transformed the everyday life of people around the world and created new social habits and even their approach to learning. This rapid technological revolution provides a different - mobile approach to learning for today's students who grow up in the digital age (Sarrab, 2015).

M-learning can be defined as the ability to use a mobile device to support the process of teaching and learning (Masrom et al., 2016) and it is considered a new platform for distance learning. Electronic learning by mobile devices is described as learning anytime, anywhere (Uhlig et al., 2005), where M-learning is considered to be a natural evolution of E-learning with efficient communication consisting of powerful and personalized mechanisms (Moreira et al., 2017). Mobile technology can be seen as a paradigm in which the mode of education is generally changing. This is also significantly reflecting on higher education (Moreira et al., 2017, Bond et al., 2020), in which this concept of learning is widely used today as a learning aid (Koruc \& Alkan, 2011; Chang et al., 2016), where students only need a mobile device and a wireless network.

The motive for examining mobile learning in different contexts and different target groups is explained in the research of Duru, Peker, and Akcakýn (2010). In this study, the student's positive attitudes towards using computers in learning mathematics were confirmed. Accordingly, in their study, Shin et al. (2011) investigated the effect of game technology on learning Mathematics, where students who played technology-based arithmetic games outperformed students who played paper-based arithmetic games, which showed the positive effects of using information and communication technologies. Similarly, the research of Briz-Ponce, Pereira, Carvalho, Juanes-Mendez, and Garcia-Penalvoa (2017) was based on the model of accepting and using mobile technology among medical science students, with the model pointing to a pattern of behaviour based on experience and ease of perception of the performance through its application.

Based on the review of the relevant literature sources, the issues regarding implementation of M-learning in technical sciences, which requires extensive experimental work both in laboratories and in the field, have not been adequately researched. The aim of this paper is to examine the application of M-learning among students of four different academic disciplines of engineering sciences and thereby to carry out the ranking of individual study programmes based on the observed criteria.

\section{Literature Review}

There have been some expected and rapid changes in the concept of learning, especially in higher education institutions, over the past ten years. The use of M-learning is increasingly prevalent (Milosevic et al., 2015) and Internet and mobile computing devices have increased educational opportunities. This rapid evolution is complemented by generations of students born in the era of digital technology, which leads to a significantly different approach to learning.

Many authors have recognized the benefits of M-learning, such as O'Malley et al. (2005) who stated that this type of learning increased the flexibility of transferring responses, as well as the feeling of freedom of movement among students. Through M-learning, the students remained connected with the student environment, although they did not have to be physically present at all times (Yi et al., 2009). Also, the good side of this type of support to the traditional way of learning could be recognized in the increased motivation of students, better co-ordination of team activities, faster responsiveness in providing answers, as well as in the increased level of communication on relation student - student and student - professor (Katic et al., 2017).

The expansion of the use of mobile phones and tablets also has an impact on changes in learning and knowledge management, which can be seen from an increasing number of researcher papers on this topic over the past few years (Table 1). Little (2013) pointed out that due to the development of mobile technology, there was an increased use of mobile devices for educational purposes (Little, 2013). However, Ozdamli \& Cavus (2011) suggested it could be very useful to enrich standard learning methods with additional online activities beyond the classroom (Ozdamli \& Cavus, 2011). Ramble and Bere (2013) concluded that the use of mobile technologies resulted in increased participation of students in creative pedagogical activities. Table 1 presents the literature review of the concept of M-learning in higher education. 
Table 1: Literature review of the concept of M-learning in higher education

\begin{tabular}{|c|c|c|}
\hline Year & Author(s) & Brief description \\
\hline 2017 & $\begin{array}{l}\text { Moreira, F., Pereira, C. S., } \\
\text { Durão, N., Ferreira, M.J. }\end{array}$ & $\begin{array}{l}\text { This paper examined the perception of professors who work in } \\
\text { higher education and use M-learning in Portugal and Spain, } \\
\text { analyzing their needs and identifying how they could be used to } \\
\text { advance students' engagement inside and outside of the classroom. } \\
\text { Most professors, who were included in this research, suggested that } \\
\text { they could effectively incorporate M-learning into the classroom } \\
\text { without additional training. }\end{array}$ \\
\hline 2017 & Hamidi, H., Chavoshi., A. & $\begin{array}{l}\text { This study analyzed factors that affected the students' acceptance } \\
\text { and use of mobile systems in Iran, such as ease of use factor, } \\
\text { usefulness factor, trust factor, features, and personal characters of } \\
\text { students. The results indicated that the context of application and } \\
\text { usefulness had a significant positive effect on the ease of use factor, } \\
\text { and trust had a positive and significant effect on the behavioural } \\
\text { intention factor as well. }\end{array}$ \\
\hline 2017 & $\begin{array}{l}\text { Briz-Ponce, L., Pereira, A., } \\
\text { Carvalho, L., Juanes- } \\
\text { Méndez, J.A., García- } \\
\text { Peñalvoa, F.J }\end{array}$ & $\begin{array}{l}\text { This research examined the different factors and drivers that had an } \\
\text { influence on students' behaviour into the usage of mobile } \\
\text { technologies for learning. Findings indicated that the students' ease } \\
\text { of perception was the main factor affecting the social Influence, and } \\
\text { the reliability for recommending this technology for learning was the } \\
\text { main factor that affected the behavioural intention. }\end{array}$ \\
\hline 2016 & $\begin{array}{l}\text { Chang, Y-S., Chien, Y-H., } \\
\text { Yu, K-C., Lin, H-C., Chen, } \\
\text { M.Y-C. }\end{array}$ & $\begin{array}{l}\text { This study analyzed how cloud-based M-learning affected students' } \\
\text { perceptions of creative performance and innovative environments. } \\
\text { The results of the research indicated that there was a positive } \\
\text { connection between perceptions of innovative environments and } \\
\text { creative performance. Moreover, M-learning based on the cloud had } \\
\text { significant effect on overall perceptions of innovative environments } \\
\text { based on features such as motivation from the head, team support, } \\
\text { and enough resources. Also, the results of the research indicated } \\
\text { that M-learning based on the cloud had positive effects on students' } \\
\text { overall creative products, their novelty, and usefulness. }\end{array}$ \\
\hline 2015 & Alioon, Y., Delialioglu, O. & $\begin{array}{l}\text { The aim of the paper was to find out and highlight the main aspects } \\
\text { that had considerable impact on M-learning and to make a frame } \\
\text { that could enable scientific researchers to better understand M- } \\
\text { learning projects and studies. Frequently considered issues in } \\
\text { investigating M-learning projects for choosing instructional methods } \\
\text { were similar and focused on M-learning in terms of engagement of } \\
\text { students. The results indicated that game-based learning and } \\
\text { inquiry were commonly used instructional methods in M-learning } \\
\text { projects and smartphones were the most frequently used devices. }\end{array}$ \\
\hline 2015 & $\begin{array}{l}\text { Garcia-Cabot, A., De- } \\
\text { Marcos, L., Garcia-Lopez, E. }\end{array}$ & $\begin{array}{l}\text { This paper considered the performance of learning and attitude of } \\
\text { graduate students when they used an adaptive mobile system that } \\
\text { tailored learning contents to their skills, their device, and current } \\
\text { context. Results indicated that mobile adaptation had a limited } \\
\text { impact on learning performance of practical skills when compared } \\
\text { to an E-learning approach. Within the same study information about } \\
\text { the context of the use of the mobile system was also collected and } \\
\text { compared with traditional computer accesses, and it indicated that } \\
\text { students learned in a similar context independently of the way that } \\
\text { they used to access learning contents. }\end{array}$ \\
\hline 2016 & Sabah, N.M. & $\begin{array}{l}\text { This research analyzed students' awareness and perceptions of M- } \\
\text { learning and examined the factors affecting students' behavioural } \\
\text { intention to adopt M-learning in Palestine. The obtained results } \\
\text { showed that perceived usefulness and perceived ease of use were } \\
\text { primary factors driving students' intentions to use m-learning. } \\
\text { Furthermore, M-learning services and social influence had positive } \\
\text { effects on the acceptance of m-learning. Generally, this study } \\
\text { indicated that students had a positive attitude and potential to } \\
\text { integrate mobile technology into their educational system. }\end{array}$ \\
\hline
\end{tabular}




\begin{tabular}{|c|c|c|}
\hline Year & Author(s) & Brief description \\
\hline 2015 & $\begin{array}{l}\text { Khan, A.I., Al-Shihi, H., Al- } \\
\text { khanjari, Z.A., Sarrab, M. }\end{array}$ & $\begin{array}{l}\text { The aim of this paper was to help the creators of education in } \\
\text { developing countries (Middle Eastern countries) overcome the } \\
\text { challenges of M-learning following the practice of developed } \\
\text { countries. Based on the experience of using M-Learning in the } \\
\text { educational system of advanced countries, the authors indicated } \\
\text { that the full realization of the potentials of mobile devices in the } \\
\text { educational process was a complex and multi-dimensional process, } \\
\text { consisting of both financial and non-financial investments (that } \\
\text { involved educational, economic, social, cultural, and technical } \\
\text { aspects, institutional willingness, and teaching ability). }\end{array}$ \\
\hline 2015 & Mohammadi, $\mathrm{H}$. & $\begin{array}{l}\text { The purpose of this paper was to examine the proposed constructs } \\
\text { in the context of M-learning in Iran based on an integrated model of } \\
\text { the Technology Acceptance Model and Expectation Confirmation } \\
\text { Theory. The results showed that intention and user satisfaction } \\
\text { predicted the actual use of M-learning between the students. } \\
\text { Moreover, the perceived image and subjective norm were found to } \\
\text { be the most important antecedents of user intention towards the use } \\
\text { of M-learning. }\end{array}$ \\
\hline 2015 & $\begin{array}{l}\text { Milosevic, I., Zivkovic, D., } \\
\text { Manasijevic, D., Nikolic, I. }\end{array}$ & $\begin{array}{l}\text { The aim of this paper was to investigate the use of mobile devices } \\
\text { for M-learning among students in Serbia using SEM methodology. } \\
\text { The results indicated that the expected performance and personal } \\
\text { innovative capabilities had the most significant influence on the } \\
\text { intended behaviour of students during the use of M-learning. }\end{array}$ \\
\hline
\end{tabular}

In many studies students are in the focus when analyzing intention to use and implement M-learning for educational purposes (Hamidi \& Chavoshi, 2017; Briz-Ponce et al., 2017; Chang et al., 2016). Based on the analysis of the state of the art of M-learning it can be concluded that all analyzed scientific papers mainly focused on testing hypotheses based on SEM methodology and analyzed various aspects of using Mlearning in the process. The crucial difference between current studies and this research is the application of PROMETHE/GAIA multi-criteria decision method (MCDM), which is based on ranking more alternatives according to different criteria at the same time. The scientific contribution of this paper is reflected in the application of MCDM methodology in order to perform the ranking of the study programmes in engineering sciences, in regard to the adaptation and implementation of M-learning.

\section{Performance Criteria and Research Model}

Numerous efforts and attempts to develop a universal research model in the field of M-learning have not offered an adequate theoretical solution. In this study the proposed theoretical model uses the following criteria for the ranking of the study programmes: Performance Expectancy, Effort Expectancy, Lecturer's Influence, Quality of Service, Personal Innovativeness, and Intention of Behaviour.

\subsection{Performance Expectancy (C1)}

M-learning Performance expectancy criterion evaluates the usefulness of M-learning as the opportunity for quick access to information, anytime and anywhere, for further knowledge acquisition (Milosevic et al., 2015).

\subsection{Effort Expectancy (C2)}

The expected students' effort to use M-learning refers to the assessment of ease of use, which is reflected in the easy and quick acceptance of the application and does not require much effort (Gao et al., 2011; Hamidi \& Chavoshi, 2017). 


\subsection{Lecturer's Influence (C3)}

The use of mobile devices in education, and especially in higher education institutions, depends primarily on the professor's attitude towards new technologies. Therefore, the role of the professor in spreading this concept is very important. Frequent use of mobile devices does not mean that professors and students are ready for M-learning. According to Ozdamli and Uzunboy (2015), it was not enough to integrate technology into education without proper use because the technology itself did nothing to improve pedagogy and increase the level of knowledge transfer. However, the influence of professors in the use of technology in teaching influenced students' motivation to apply innovations (Koc, 2013), thus encouraging students to adapt more easily to the use of new technologies for the purpose of learning.

\subsection{Quality of Service (C4)}

The quality of M-learning services is based on the benefits of information technology which are primarily manifested in the use of the Internet and multimedia systems, thus facilitating access to resources (Hao et al., 2017) and improving information search speed and speed of information acquisition.

\subsection{Personal Innovativeness (C5)}

Personal innovativeness can be used in a technological context for the adoption and use of new devices, where desire, need, and personal perception play an important role in adaptation of technology (Milosevic et al., 2015).

\subsection{Intention of Behaviour (C6)}

The intention of behaviour factor refers to the individual desires of those who make effort in a particular way, which is based on personal characteristics, ease of use, and factors of confidence (Hamidi \& Chavoshi, 2017). However, when it comes to mobile technologies from the students' point of view there are limitations due to unsuccessful and unsafe Internet connection, limited memory and battery capacity, difficult navigation and download from mobile devices, especially smartphones. These constraints can cause negative intent of behaviour thus creating student's resistance to the use of M-learning (Sabah, 2016; Moreira et al., 2017).

By considering the criteria, a universal research model is defined, consisting of three parts: problem identification and data collection, construction of a multicriteria model and, finally, analysis of the results, as shown in Figure 1.

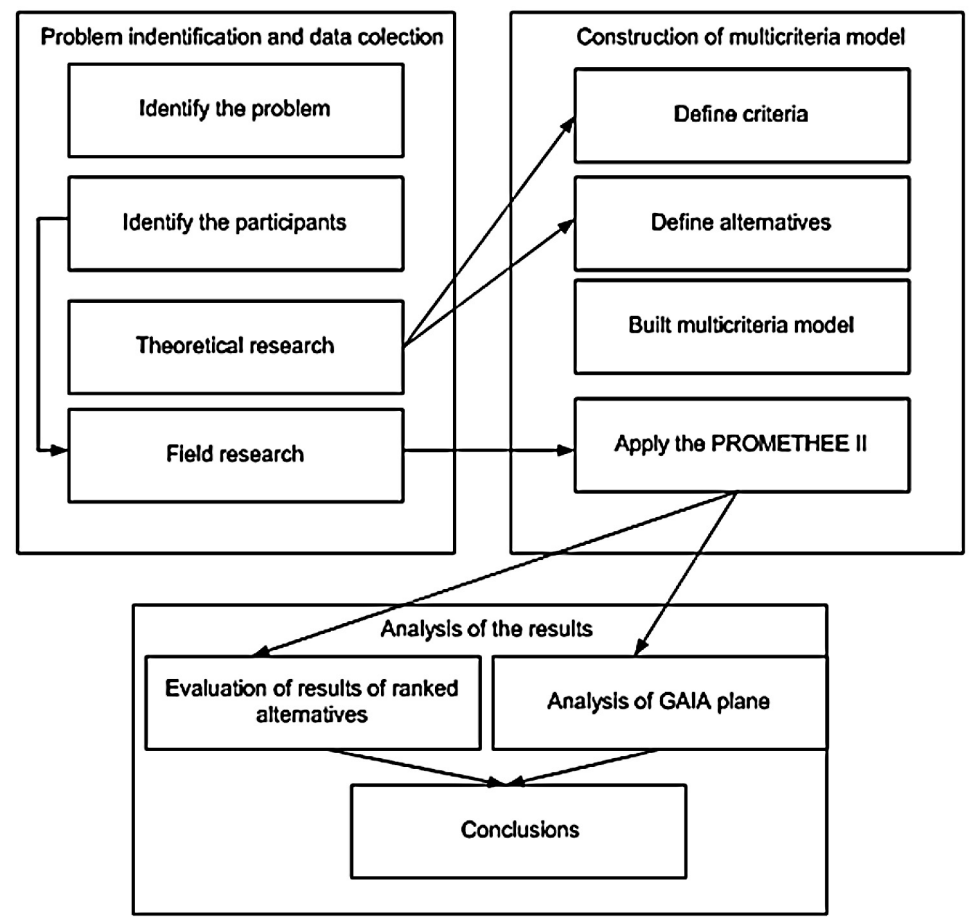

Figure 1: Universal research model applied on M- learning 


\section{Methodology}

\subsection{Questionnaire}

The first part of the research refers to the diagnosis and assessment of M-learning in a higher education institution with the aim to identify problems and shortcomings related to the use of M-learning in order to define alternatives and criteria for the proposed model.

Based on the data collected through the questionnaire (Ahmad \& Love, 2013), a relevant research base was created, which was completed at the Technical Faculty in Bor, University of Belgrade, Serbia, in 2017. The Technical Faculty in Bor (TFB) is part of the University of Belgrade (UB), which is, according to the Shanghai list, ranked among the top 500 universities in the world, which implies a high quality of teaching and scientific work (Zivkovic et al., 2017). The TFB teaches a group of technology and engineering sciences, and today it has four study programmes: Mining Engineering, Metallurgical Engineering, Chemical Engineering, and Engineering Management, with a total number of about 1400 students. The research was carried out among students of the four mentioned study programs, which represented the alternatives of the defined model.

The survey was conducted through a questionnaire, where 341 correctly filled out questionnaires were collected. The survey was anonymous, and the obtained data were processed by the Visual PROMETHEE software package. Data processing in this software package was based on the application of the MultiCriteria Decision-Making tool, that is, the application of the PROMETHEE/GAIA methodology which enabled adequate ranking of analyzed study programmes based on predefined criteria.

The criteria were defined on the basis of the six dimensions from the questionnaire (Ahmad \& Love, 2013) used for the application of M-learning in higher education. These criteria belonged to a group of unidimensional factors which were comprised of the following criteria: Performance Expectancy, Effort Expectancy, Lecturer's Influence, Quality of Service, Personal Innovativeness, and Intention of Behaviour. All criteria were qualitative and the way of choosing questions represented a structured and logical approach to assessing the importance of preferences through Likert five-point scale in order to quantify the subjective opinion of the respondents and establish a link between alternatives and criteria. The method was simple and easy to understand, leading to high research efficiency.

\subsection{PROMETHEE - GAIA method}

PROMETHEE and GAIA belong to a group of multi-criteria methods for decision making. The Preference Ranking Organization Method for Enrichment Evaluations method includes several unique tools developed in the 1960s by Brans (Brans, 1982) and since then it has improved in terms of methodology and numerous software packages for its thorough application have been developed (Brans et al.,1986; Brans \& Mareschal, 1994). The PROMETHEE method is complemented by GAIA, which represents a graphical presentation of the obtained ranking (Mareschal \& Brans, 1988). A visual representation of a multi-criteria problem enables a better understanding of the possible choices and necessary compromises in order to obtain the best solution. The PROMETHEE and GAIA methods have been widely used in scientific research since their occurrence in the fields of business planning, energy, occupational safety, education, information technology, etc. (Brans, 2002; Chen et al., 2011; Milijic et al., 2014; Kilic et al., 2015), hence, the precondition for using this methodology in this type of research has been fulfilled.

Based on the review of the relevant literature, it was found that the PROMETHEE/GAIA method has not been applied in the field of M-learning so far. This paper proposes the approach to ranking of certain study programmes based on the PROMETHEE method which is considered as one of the most important methods for multi-criteria decision-making based on the outranking approach. The first phase in the application of the method is the definition of the structure of preferences where, through generalized functions, the divergence among evaluations is taken into account. Then, in the second phase, the outranking relations among compared alternatives are established and these relations represent the dominance of one alternative over the others, where all the criteria are taken into account. The third phase refers to the conclusion of the range of alternatives where PROMETHEE II provides the overall ranking of alternatives (Brans \& Mareschal, 1994). The implementation of the PROMETHEE/GAIA method used in this study consists of the following steps (Zivkovic et al., 2017):

Step 1: Creating the decision table. The issue of ranking by multi-criteria assessment involves a set of criteria (C) and a set of possible alternatives (A) based on which the decision-making table is created. Additional information which is necessary for ranking the alternatives is information concerning the relationship among criteria and these represent the weight or relative significance of each criterion $\left(w_{j}\right)$. 
Step 2: Assigning the preference function to each criterion. The second group of needed information relates to the preference function $\mathrm{P}_{\mathrm{j}}(\mathrm{a}, \mathrm{b})$. The function of preference represents the difference between the estimated values $a$ and $b$ according to the criterion to which the given function relates to (Brans, 2002). The degree of preference represents the growing function of deviation, and if the deviation is small, it represents a low preference of the alternative $a$ in relation to $b$, while if the deviation is large it represents a strong preference of the observed alternative $a$ in relation to $b$. There are 6 specific forms of preference functions: Usual shape, U-shape function, V-shape function, Level function, Linear function, and Gaussian function (Brans \& De Smet, 2016) which enable an easy information acquisition for further use of the PROMETHEE/GAIA method.

Step 3: Calculating the preference index $\pi(a, b)$, based on the weights of the criteria

$$
\pi(a, b)=\sum_{j=1}^{n} w_{j} \cdot P_{j}(a, b)
$$

Step 4: Calculating outranking flows for each alternative. The PROMETHEE II method determines the positive $(\Phi+)$ and negative $(\Phi-)$ flows for each alternative. A positive flow of preference expresses the extent of dominance of one particular alternative over the other alternatives, while the negative flow of preference expresses the extent to which a particular alternative is preferred by other alternatives:

$$
\begin{aligned}
& \Phi^{+}(a)=\frac{1}{n-1} \sum_{x \in A} \pi(a, x) \\
& \Phi^{-}(a)=\frac{1}{n-1} \sum_{x \in A} \pi(x, a)
\end{aligned}
$$

where $n$ is the number of alternatives.

The PROMETHEE II method enables the overall ranking of alternatives by calculating the net flow $(\Phi)$ which represents the difference between the positive and the negative flow preferences (Nikolic et al., 2009).

$$
\Phi(a)=\Phi^{+}(a)-\Phi^{-}(a)
$$

\subsection{Data analysis and results}

The criteria used in this paper by applying the multi-criteria decision method were maximized (Table 2) and defined on the basis of the nature of the specific criteria which were thoroughly described in the preceding text. In a previous paper on this topic (Milosevic et al., 2015), the authors confirmed the validity of the measurement scale of each selected criterion using exploratory and confirmatory factor analysis. Therefore, each criterion in this paper had a value obtained by calculating the mean value of the respondents' answers to all questions that determine the given criterion. The results of those calculations are given in Table 2. The preference function of type 1- Usual was used, which was the most acceptable for qualitative criteria based on the assessments from a survey and possible values were low (Mareschal, 2018; Podvezko \& Podviezko, 2010; Abdullah et al., 2019). Usual preference function did not have thresholds and each difference among alternatives, according to a given criterion, higher than 0 produced absolute preference.

Table 2: Initial data for the PROMETHEE MCDA technique

\begin{tabular}{|l|l|l|l|l|l|l|}
\hline & $\begin{array}{l}\text { Performance } \\
\text { Expectancy } \\
\text { (C1) }\end{array}$ & $\begin{array}{l}\text { Effort } \\
\text { Expectancy } \\
\text { (C2) }\end{array}$ & $\begin{array}{l}\text { Lecturer' } \\
\text { Influence } \\
\text { (C3) }\end{array}$ & $\begin{array}{l}\text { Quality of } \\
\text { Service } \\
\text { (C4) }\end{array}$ & $\begin{array}{l}\text { Personal } \\
\text { Innovativeness } \\
\text { (C5) }\end{array}$ & $\begin{array}{l}\text { Intention of } \\
\text { Behaviour } \\
\text { (C6) }\end{array}$ \\
\hline Weights & 16.67 & 16.67 & 16.67 & 16.67 & 16.67 & 16.67 \\
\hline Max/min & Max & Max & Max & Max & Max & Max \\
\hline Preference function & Usual & Usual & Usual & Usual & Usual & Usual \\
\hline $\begin{array}{l}\text { Engineering } \\
\text { Management (A1) }\end{array}$ & 3.2985 & 3.7887 & 3.5476 & 3.5482 & 3.5630 & 3.8257 \\
\hline $\begin{array}{l}\text { Mining Engineering } \\
\text { (A2) }\end{array}$ & 3.3840 & 3.7884 & 3.5128 & 3.4871 & 3.4871 & 3.7076 \\
\hline $\begin{array}{l}\text { Chemical } \\
\text { Engineering (A3) }\end{array}$ & 3.2666 & 3.7083 & 3.4074 & 3.6250 & 3.5648 & 3.4500 \\
\hline $\begin{array}{l}\text { Metallurgical } \\
\text { Engineering (A4) }\end{array}$ & 3.2929 & 3.5681 & 2.8787 & 3.3636 & 3.5151 & 3.5454 \\
\hline
\end{tabular}


The results of ranking obtained by using PROMETHEE II methodology are shown in Table 3 and Figure 2.

Table 3: Results of the complete ranking of study programmes by using the PROMETHEE II method

\begin{tabular}{|c|l|c|c|c|}
\hline Rank & \multicolumn{1}{|c|}{ Alternative } & Phi $^{+}$ & Phi $^{-}$ & Phi \\
\hline 1 & Engineering Management & 0.8333 & 0.1667 & 0.6667 \\
\hline 2 & Mining Engineering & 0.5556 & 0.4444 & 0.1111 \\
\hline 3 & Chemical Engineering & 0.4444 & 0.5555 & -0.1111 \\
\hline 4 & Metallurgical Engineering & 0.1667 & 0.8333 & -0.6667 \\
\hline
\end{tabular}

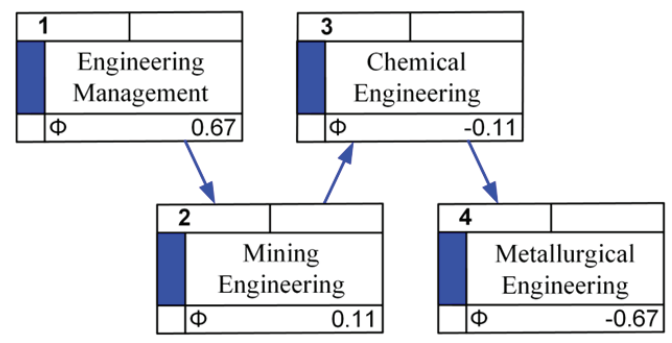

Figure 2: PROMETHEE II - Results of the complete ranking

The GAIA plane shown in Figure 3, represents a visual presentation of the performed ranking, which shows the comparison of all alternatives according to each criterion. The criteria presented with squares in the GAIA plane (Figure 3) indicated that there were no significant conflicts between the criteria since they were not leaning in opposite directions. Criteria placed closer to each other suggested that respondents equally valued both. In this case, the criteria with the most similar estimates were Effort Expectancy (C2) and Lecturers' Influence (C3). The axis direction of the decision stick (pi stick), showed which criteria were the most responsible for the ranks obtained by the PROMETHEE method. The GAIA plane indicated that the alternatives, presented with triangles, were diffused and did not make any clusters. The best-ranked alternative (Engineering Management) was the closest to the pi stick and its location pointed to the criteria in which alternative was mainly good. The percentage of data collection in the GAIA plane, i.e., the reliability of the given graphic interpretation was quite high $(\Delta: 95.57 \%)$, which was more than satisfactory according to Brans \& Mareschal (1994) who regarded each value over $60 \%$ as acceptable.

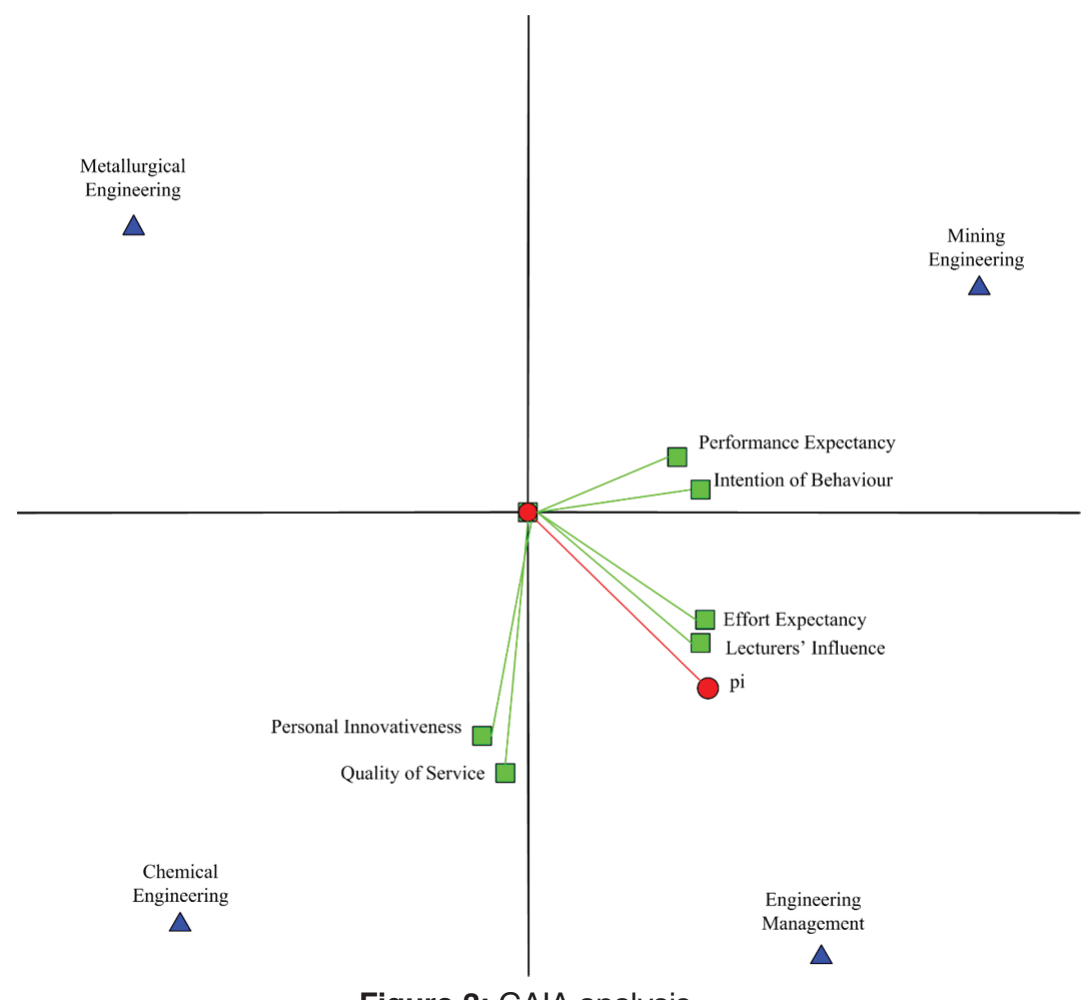

Figure 3: GAIA analysis 
In this paper, equal weight values were assigned to all criteria when conducting the ranking. However, the additionally analyzed results of the ranking changed due to the variation of the criteria weights, using stability intervals presented in Table 4. The results of the sensitivity analysis represented the limits within which the weight of a particular criterion could be changed without changing the order of the ranked alternatives. Changing the weight of criteria Performance Expectancy (C1), Quality of Service (C4), and Personal Innovativeness (C5) could change the position of the first-ranked alternative, while the remaining three criteria did not have that power.

Table 4: Stability intervals

\begin{tabular}{|l|l|l|}
\hline & Criterion & Stability interval \\
\hline (C1) & Performance Expectancy & $0.062-0.545$ \\
\hline (C2) & Effort Expectancy & $0.000-\infty$ \\
\hline (C3) & Lecturers' Influence & $0.000-\infty$ \\
\hline (C4) & Quality of Service & $0.286-0.615$ \\
\hline (C5) & Personal Innovativeness & $0.250-0.615$ \\
\hline (C6) & Intention of Behaviour & $0.545-\infty$ \\
\hline
\end{tabular}

\section{Discussion}

The position of the alternatives in the GAIA plane (Figure 3) determines their strength or weakness in relation to the selected criteria. The results showed that the Engineering Management study programme exhibited the best performances given that this alternative was the closest to the axis of the criterion almost by all criteria, as indicated by the vector pi (the decision bar). The alternative which was the closest to the decisionmaking bar was considered to be the best and in this case it was the Engineering Management. On the other hand, the worst alternative was the one associated with the lowest scores according to all criteria and that had the opposite direction from the decision bar, which was the position of the alternative Metallurgical Engineering in this case.

Based on the observation of the criterion axes, the criteria of Lectures Influence, Quality of Services, and Intentions of Behaviour had higher influence than the remaining three criteria. It should also be pointed out that quality of the model could be deemed as satisfactory, as there were no pronounced conflicts among them. In other words, there were no two criteria that were positioned opposite each other in the GAIA plane (Figure 3).

The obtained results showed that M-learning was mostly used by the students of Engineering Management, since they encountered mobile technology more frequently in certain required courses, as well as during the compulsory business practice. Based on their position shown in the GAIA plane (Figure 3), criteria which influenced Engineering Management the most were Lecturer's Influence and Effort Expectancy. The Lecturer's Influence represented an important incentive for students to use new technologies for the purpose of learning and for helping them adapt to it more easily. Effort Expectancy referred to ease of use and self-efficacy in mastering technology, whereby students would be certain that the M-learning system satisfied their needs and values. This result was expected because the use of communication in teaching via mobile phones was the most common for this profile of students. Modern business practices, about which students learned and strove for, could not be imagined without appropriate and modern telecommunication technologies.

The second-ranked department, according to the results of the analysis, was Mining Engineering. The criteria which influenced this orientation the most were Performance Expectancy and Intention of Behaviour. Expected performances in the context of M-learning showed that students of Mining Engineering could improve their productivity in learning which would be reflected, through Intention of Behaviour, on active experimentation in their practical work.

The criteria Personal Innovativeness and Quality of Service, based on their position in the GAIA plane (Figure $3)$, had the most influence on the third-ranked study programme, Chemical Engineering. The way in which the service was provided to users of M-learning could significantly affect the level of acceptance of the new technology, therefore the quality of the service provided could be considered a key factor for initiating innovation among students. It was expected that students of this orientation had a greater degree of innovativeness due to the possibility of creating innovative solutions when the experiments were conducted. Based on the obtained results, it was determined that the Metallurgical Engineering study programme delivered the poorest performance regarding the implementation M-learning among all other analyzed study programmes, since it was ranked as poorest on the basis of all the criteria and its position in the GAIA plane was diametrically opposite to the decision-making bar. 
Conslusion

Informatization of a society is the ongoing process which is showing no indications of slowing down. Accordingly, students are those who keep up with technological trends, and M-learning is no longer a choice but a necessity in a modern approach to learning. Hence, mobile learning represents an implementation of digital technologies in order to contribute to, adjust, address, and aid learning in different situations, and it has confirmed its usefulness in the crisis period. The phenomenon of the new virus COVID 19 which caused a pandemic around the world has affected the traditional education system. The higher education institutions all over the world were forced to respond to the challenge and ensure the desired level of quality of the teaching process in the online environment (Rakic et al., 2020). Therefore, it was necessary to make a rapid transition from traditional to online learning that further influenced the increased use of tools and devices needed for M-learning (Naciri et al., 2020). In this paper, student perceptions were studied in four different study programmes (Mining Engineering, Technology Engineering, Metallurgical Engineering, and Engineering Management) at the Technical Faculty in Bor, University of Belgrade, Serbia.

On the basis of the applied methodology of multi-criteria decision making, the ranking was conducted using PROMETHEE/GAIA methodology, based on which the conclusion was drawn that students of Engineering Management kept pace with the technology more than students from other study programmes because they were more willing to incorporate this modern approach to learning, as well as to experiment with new information technologies. In line with it, the students in Portugal and Spain inferred that it was fun to use interactive mobile devices in the classroom (Moreira et al., 2017). Students have been increasingly in favour of adopting M-learning for the advantages it brought them and its ease to use (Little, 2013). The perceived understanding of users contributed to successful adoption of a system, such as the Mlearning system, where the student would be able to better explore data mining algorithms and to acquire better understanding of the proposed algorithms (Delibasic et al., 2013).

When it comes to the students of the three remaining programs of study, communication via mobile devices in learning was less present as these students had more practical work in the field and in the laboratory. In addition, in the study carried out by Milosevic et al. (2015) it was found that Effort Expectancy had the least influence on the intended behaviour of students because students considered that they needed to make additional efforts to master the skills of M-learning. These students were prone to hypothetical-deductive thinking and experimentation; they preferred to approach solving technical problems rather than engaging in social and interpersonal ones.

Although theoretical and practical aspects of teaching differ among these four study programmes, M-learning mechanisms can be used to overcome constraints in the traditional learning approach. M-learning should link formal educational practice (e.g., student activity during lectures, participation in workshops, experimental work) with informal situational learning practices (e.g., support for solving tasks by using mobile devices).

This study has certain limitations, which are reflected primarily in the fact that data were collected only at one faculty in the field of engineering sciences. One of its primary goals is to represent a foundation for future research which will focus on a larger number of technical groups of study programmes, which will provide more representative results on both usefulness and application of M-learning.

\section{Acknowledgments}

The research presented in this paper was done with the support of the Ministry of Education, Science and Technological Development of the Republic of Serbia, within the funding of the scientific research work at the University of Belgrade, Technical Faculty in Bor, according to the contract with registration number 451-03-68/2020-14/ 200131. Also, responsible for the English language in the paper is Sandra Vasković, English language teacher.

\section{REFERENCES}

[1] Abdullah, L., Chan, W., \& Afshari, A. (2019). Application of PROMETHEE method for green supplier selection: a comparative result based on preference functions. Journal of Industrial Engineering International 15, 271-285. DOI:10.1007/s40092-018-0289-z

[2] Ahmad, A., \& Love, S. (2013). Factors influencing students' acceptance of m-learning: An investigation in higher education. The International Review of Research in Open and Distance Learning, 14(5), 83-107. DOI: $10.19173 /$ irrodl.v14i5.1631

[3] Alioon, Y., \& Delialioglu, O. (2015). A Frame for the Literature on M-learning. 4th World Conference on Educational Technology Researches, WCETR-2014, Procedia - Social and Behavioral Sciences, 182, 127-135. DOI: 10.1016/j.sbspro.2015.04.747 
[4] Bond, M., Buntins, K., Bedenlier, S., Zawacki-Richter, O., \& Kerres, M. (2020). Mapping research in student engagement and educational technology in higher education: A systematic evidence map. International Journal of Educational Technology in Higher Education, 17(1), 2.DOI: 10.1186/s41239-0190176-8

[5] Bower, M., Cram, A., \& Groom, D., (2010). Blended reality: issues and potentials in combining virtual worlds and face-to-face classes. In: Curriculum, Technology \& Transformation for an Unknown Future. Sydney. pp. 129-140.

[6] Brans, J. (1982). The Engineering of Decision: Elaboration Instruments of Decision Support Method PROMETHEE. Quebec, Canada: Laval University.

[7] Brans, J. (2002). Ethics and decision. European Journal of Operational Research 136, 340-352. DOI:10.1016/S0377-2217(01)00121-7

[8] Brans, J., \& De Smet, Y. (2016). PROMETHEE Methods. In S. Greco, M. Ehrgott, \& J. Figueira, Multiple Criteria Decision Analysis. International Series in Operations Research \& Management Science, vol 233. (pp. 163-195). New York, NY: Springer.

[9] Brans, J., \& Mareschal, B. (1994). The PROMCALC \& GAIA decision support system for multicriteria decision aid. Decision Support Systems 12, 297-310.

[10] Brans, J., Vincke, P., \& Mareschal, B. (1986). How to select and how to rank projects: The PROMETHEE method. European Journal of Operational Research $24,228-238$.

[11] Briz-Ponce, L., Pereira, A., Carvalho, L., Juanes-Mendez, J.A., \& Garcia-Penalvoa, F.J. (2017). Learning with mobile technologies - Students' behavior. Computers in Human Behavior, 72, 612-620.

[12] Chang, Y-S., Chien, Y-H., Yu, K-C., Lin, H-C., \& Chen, M. Y-C. (2016). Students' innovative environmental perceptions and creative performances in cloud-based m-learning. Computers in Human Behavior, 63, 988-994.

[13] Chen, Y., Wang, T., \& Wu, C. (2011). Strategic decisions using the fuzzy PROMETHEE for IS outsourcing. Expert Systems with Applications, 38, 13216-13222.

[14] Delibasic, B., Vukicevic, M., \& Jovanovic, M. I. L. O. (2013). White-box decision tree algorithms: A pilot study on perceived usefulness, perceived ease of use, and perceived understanding. International Journal of Engineering Education, 29(3), 674-687

[15] Duru, A., Peker, M., \& Akcakin,.V.(2010).Liseogren cilerinin Bilgisayar Destekli Matematik oðrenmeyeYonelikTutumlarý. Turkish Journal of Computer and Mathematics Education, 1 (3), 264-284.

[16] Gao, S., Krogstie, J., \& Siau, K., (2011). Developing an instrument to measure the adoption of mobile services. Mobile Inf. Syst. 7, 45-67.

[17] Garcia-Cabot, A., De-Marcos, L., \& Garcia-Lopez, E. (2015). An empirical study on m-learning adaptation: Learning performance and learning contexts. Computers \& Education, 82, 450-459.

[18] Hamidi, H., \& Chavoshi., A., (2017). Analysis of the essential factors for the adoption of mobile learning in higher education: A case study of students of the University of Technology, Telematics and Informatics, DOI:10.1016/j.tele.2017.09.016.

[19] Hao, S., Dennen, V. P., \& Mei, L. (2017). Influential factors for mobile learning acceptance among Chinese users. Educational Technology Research and Development, 65(1), 101-123.

[20] Katic, A., Vukadinovic, S., \& Brkanlic, S. (2017). Primena mobilnih aplikacija u obrazovanju M - Učenje. XXIII Skup TRENDOVI RAZVOJA: "Položaj visokog obrazovanja i nauke u srbiji", Zlatibor, T1.1-6, 1-4.

[21] Khan, A.I., Al-Shihi, H., Al-khanjari, Z.A., \& Sarrab, M. (2015). Mobile Learning (M-Learning) adoption in the Middle East: Lessons learned from the educationally advanced countries. Telematics and Informatics, 32, 909-920.

[22] Kilic, H., Zaim, S., \& Delen, D. (2015). Selecting “The Best” ERP system for SMEs using a combination of ANP and PROMETHEE methods. Expert Systems with Applications, 42, 2343-2352.

[23] Koc, M. (2013). Student teachers' conceptions of technology: A metaphor analysis. Computers \& Education, 68, 1-8.DOI:10.1016/j.compedu.2013.04.024.

[24] Korucu, T., \& Alkan, A. (2011). Differences between m-learning (mobile learning) and e-learning, basic terminology and usage of m-learning in education. Social and Behavioral Science, 15, 1925-1930.

[25] Little, B. (2013). Issues in mobile learning technology. Human Resource Management International Digest, 21 (3), 26-29.

[26] Mareschal, B. (2018). Preference functions and thresholds. Retrieved August 8, 2020, from http://www.promethee-gaia.net/FR/assets/preffunctions.pdf

[27] Mareschal, B., \& Brans, J. (1988). Geometrical representations for MCDA. European Journal of Operational Research, 34 (1), 69-77.

[28] Masrom, M., Nadzari, A.S., \& Zakaria S.A. (2016). e-Proceeding of the 4th Global Summit on Education GSE 2016, 268-276.

[29] Milijic, N., Mihajlovic, I., Nikolic, D., \& Zivkovic, Z. (2014). Multicriteria analysis of safety climate measurements at workplaces in production industries in Serbia. International Journal of Industrial Ergonomics, 44, 510-519. 
[30] Milosevic, I., Zivkovic, D., Manasijevic, D., \& Nikolic, I., (2015), 'The effects of the intended behavior of students in the use of M-learning, Computers in Human Behavior 51, 207-215.

[31] Mohammadi, H. (2015). Social and individual antecedents of m-learning adoption in Iran. Computers in Human Behavior, 49, 191-207.

[32] Moreira, F., Pereira, C. S., Durão, N., \& Ferreira, M.J. (2017). A comparative study about mobile learning in Iberian Peninsula Universities: Are professors ready?. Telematics and Informatics, DOI:10.1016/j.tele.2017.09.010.

[33] Naciri, A., Baba, M. A., Achbani, A., Kharbach, A. (2020). Mobile Learning in Higher Education: Unavoidable Alternative during COVID-19. Aquademia, 4(1), ep20016. DOI:10.29333/aquademia/8227

[34] Nikolic, D., Jovanovic, I., Mihajlovic, I., \& Zivkovic, Z. (2009). Multi-criteria ranking of copper concentrates according to their quality - An element of environmental management in the vicinity of copper - Smelting complex in Bor, Serbia. Journal of Environmental Management 91 , 509-515.

[35] O'Malley, C. et al. (2005). MOBllearn-Guidelines for Learning/Teaching/Tutoring in a Mobile Environment. Nottingham: University of Nottingham, 82 p. (Pedagogical Methodologies and Paradigms, WP). Retrieved from

http://hal.archives-ouvertes.fr /docs/00/69/62/44/PDF/OMalley-2005.pdf

[36] Ozdamli, F., \& Uzunboylu, H. (2015). M-learning adequacy and perceptions of students and teachers in secondary schools. British Journal of Educational Technology, 46(1), 159-172.DOI:10.1111/bjet.12136.

[37] Ozdamli, F., \& Cavus, N. (2011). Basic Elements and Characteristics of Mobile Learning. ProcediaSocial and Behavioral Sciences, 28, 937-942. DOI:10.1016/j.sbspro.2011.11.173

[38] Podvezko, V., \& Podviezko, A. (2010). Dependence of multi-criteria evaluation result on choice of preference functions and their parameters. Ukio Technologinis ir Ekonominis Vystymas,16:1, 143-158. DOI: $10.3846 /$ tede.2010.09

[39] Rakic, A., Ruso, J., \& Milosevic, I. (2020). E-learning as the emerging lecturing practice in the higher education industry. SymOrg 2020 (In press)

[40] Ramble, P., Bere, A. (2013). Using mobile instant massaging to leverage leaner participation and transform pedagogy at a south African University of Technology. British Journal of Educational Technology, 44(4), 544-561. DOI:10.1111/bjet.12057

[41] Sabah, N.M., (2016). Exploring students' awareness and perceptions: Influencing factors and individual differences driving m-learning adoption. Computers in Human Behavior, 65, 522-533. DOI:10.1016/j.chb.2016.09.009.

[42] Sarrab, M. (2015). M-learning in education: Omani Undergraduate students perspective. Procedia Social and Behavioral Sciences, 176, 834-839. DOI: 10.1016/j.sbspro.2015.01.547

[43] Shin, N., Sutherland, L. M., Norris, C. \& Soloway, E. (2011). Effects of game technology on elementary student learning in Mathematics.British Journal of Educational Technology. 39,981-992. DOI:10.1111/j.1467-8535.2011.01197.x

[44] Uhlig, R., Neiger, G., Rodgers, D., Kagi, A., Leung, F., Smith, H. (2005). Intel Corp., USA : Intel visualization technology IEEE Computer Society.DOI:10.1535/itj.1003

[45] Wen-Hsiung, W., Yen-Chun, J. W., Chun-Yu, C., Hao-Yun, K., Che-Hung, L., \& Sih-Han, H. (2012). Review of trends from mobile learning studies: A meta-analysis. Computers \& Education, 59, 817-827. DOI:10.1016/j.compedu.2012.03.016

[46] Yi, C.C., Liao, W.P., Huang, C.F., Hwang, I.H. (2009). Acceptance of mobile learning: a respecification and validation of information system success. In Proceedings of World Academy of Science, Engineering and Technology, 41, 2070- 3740.

[47] Zivkovic, Z., Nikolic, Dj., Savic, M., Djordjevic, P., \& Mihajlovic,I., (2017). Prioritizing Strategic Goals in Higher Education Organizations by Using a SWOT-PROMETHEE/GAIA-GDSS Model, Group Decision and Negotiation 26, 829-846. DOI: 10.1007/s10726-017-9533-y

Received: 2020-06-15 Revisions requested: 2020-07-19 Revised: 2020-08-17 (2 revisions) Accepted: 2020-09-30 


\section{Appendix:}

Survey Items Used in the Study (Ahmad et al., 2013)

Performance Expectancy (PE)

PE1. I find m-learning useful for my studies.

PE2. Using m-learning would enable me to achieve learning tasks more quickly.

PE3. Using m-learning in my studying would not increase my learning productivity.

PE4. Mobile learning could improve my collaboration with classmates.

Effort Expectancy (EE)

EE1. I would find an m-learning system flexible and easy to use.

EE2. Learning to operate an m-learning system does not require much effort.

EE3. My interaction with an m-learning system would be clear and understandable

Lecturers' Influence (LI)

LI1. I would use m-learning if it was recommended to me by my lecturers.

LI2. I would like to use m-learning if my lecturers supported the use of it.

Quality of Services (QoS)

QoS1. It is important for m-learning services to increase the quality of learning.

QoS2. I would prefer m-learning services to be accurate and reliable.

QoS3. It is preferable that $\mathrm{m}$-learning services are easy to navigate and download

Personal Innovativeness (PInn)

PInn1. I like to experiment with new information technologies.

PInn2. When I hear about a new information technology, I look forward to examining it.

Behavioural Intention (BI)

BI1. I plan to use m-learning in my studies.

$\mathrm{BI}$. I predict that I will use m-learning frequently.

BI3. I will enjoy using m-learning systems.

BI4. I would recommend others to use m-learning systems

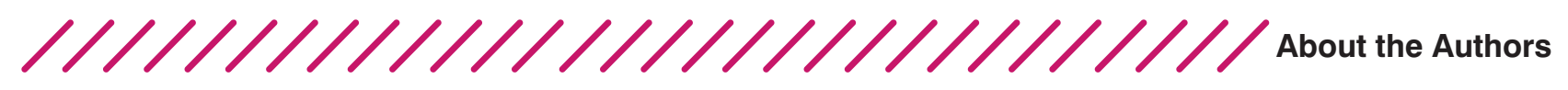

$$
\begin{array}{r}
\begin{array}{r}
\text { Isidora Milošević } \\
\text { University of Belgrade, Technical Faculty in Bor, Serbia } \\
\text { imilosevic@tfbor.bg.ac.rs }
\end{array}
\end{array}
$$

Isidora Milošević, PhD, is an Associate Professor at the Technical faculty in Bor. Her main research interests include strategic management, new technology and innovation, structural equation modelling, corporate social responsibility and marketing in small and medium-sized entreprises. She co-authored a number of research papers published in international scientific journals and has led several international research projects.

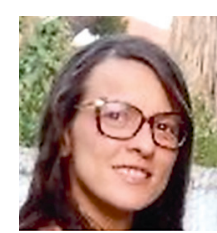

\section{Ana Rakić \\ University of Belgrade, Faculty of Organizational Sciences, Serbia ana.rakic@fon.bg.ac.rs}

Ana Rakić, PhD, is an Assistant Professor at the University of Belgrade, Faculty of Organizational Sciences. Her main research interests are quality management, standardization, metrology, accreditation, and certification. She is a co-author of many papers in international and national journals and conferences and a member of CASCO technical committee at the Institute for Standardization of Serbia.

\section{Sanela Arsić \\ University of Belgrade, Technical Faculty in Bor, Serbia saarsic@tfbor.bg.ac.rs}

Sanela Arsić, PhD, is an Assistant Professor at the Technical Faculty in Bor, University of Belgrade. She is the author and co-author of a number of papers in international and national journals and conferences on the following

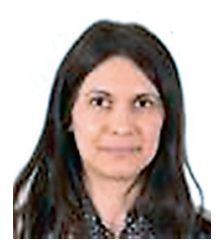
scientific areas: operational research, quality of management, corporate social responsibility, structural equation modelling.

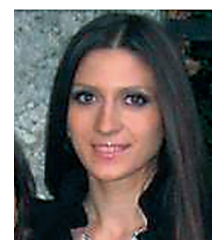


Anđelka Stojanović

University of Belgrade, Technical Faculty in Bor, Serbia anstojanovic@tfbor.bg.ac.rs

Anđelka Stojanović, PhD student, is employed at the Department of Management, Technical Faculty in Bor, University of Belgrade as an assistant for subjects: decision making theory, theory reliability, production management. She is the author and coauthor of a numbet of papers in international and national journals and conferences.

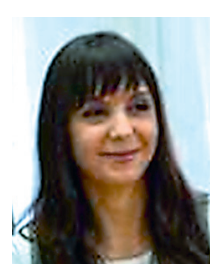

Ivica Nikolić

University of Belgrade, Technical Faculty in Bor, Serbia inikolic@ttbor.bg.ac.rs

Ivica Nikolić, PhD, is an Assistant Professor at the University of Belgrade, Technical Faculty in Bor, Department of Engineering Management. He is the author and co-author of numerous papers in international and national journals and conferences on the following scientific areas: methods of linear and nonlinear statistical analysis, environmental management, modelling business and technology processes, new technology and innovation.

\section{Predrag Đorđević University of Belgrade, Technical Faculty in Bor, Serbia pdjordjevic@tfbor.bg.ac.rs}

Predrag Đorđević, PhD, is employed at the Department of Management, Technical Faculty in Bor, University of Belgrade as an associate professor for subjects: quality of management, advanced information technology. He is the author and co-author of a number of papers in international and national journals and conferences.
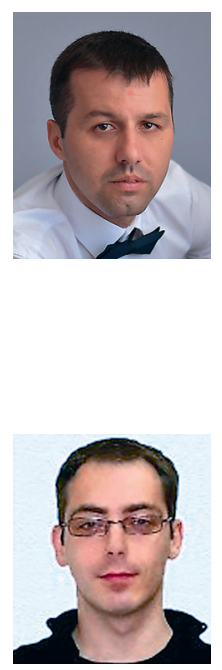